Review

\title{
Corporate social responsibility and financial performance: Evidence from U.S tech firms
}

\author{
Anthony Okafor ${ }^{\mathrm{a},{ }^{*}}$, Bosede Ngozi Adeleye ${ }^{\mathrm{b}}$, Michael Adusei ${ }^{\mathrm{c}}$ \\ ${ }^{a}$ Department of Accounting, University of Louisville, USA \\ ${ }^{\mathrm{b}}$ Covenant University, Otta, Nigeria \\ ${ }^{\mathrm{c}}$ Kwamme Nkrumah University of Science and Technology, Kumasi, Ghana
}

\section{A R T I C L E I N F O}

\section{Article history:}

Received 10 September 2020

Received in revised form

8 December 2020

Accepted 20 January 2021

Available online 27 January 2021

Handling editor: Prof. Jiri Jaromir Klemeš

\section{JEL classification:}

G28

G32

L21

M14

Keywords:

Corporate social responsibility

Corporate financial performance

Firm value

Sustainable development

Tech industry

\begin{abstract}
A B S T R A C T
This study provides quantitative evidence on the positive effect of spending on socially responsible causes on the long-term growth of U.S technology companies. Maximizing shareholder wealth remains the overarching principle driving organizational strategies, but this has always conflicted with other stakeholders' interests. Because of these conflicting priorities, entrenching the principles of social responsibility has become imperative. We leverage content analysis, fixed-effects and pooled regression models to examine the effect of engaging in CSR on tech companies' corporate financial performance in the U.S. The empirical study consists of panel data of the top 100 tech companies listed on the S\&P 500 for the period 2017 and 2019. We examine the link between corporate financial performance and CSR proxies. The main results indicate that tech companies that spend more on CSR experience a corresponding increase in revenue and profitability. Contrary to previous studies, we observe insignificant evidence to support a relationship between CSR and Tobin's Q.
\end{abstract}

(C) 2021 Elsevier Ltd. All rights reserved.

\section{Contents}

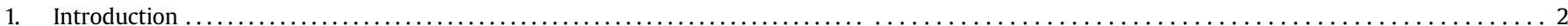

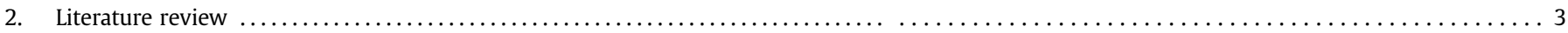

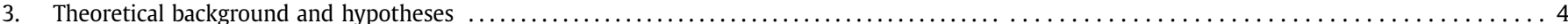

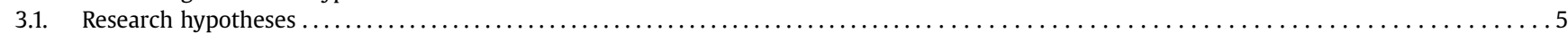

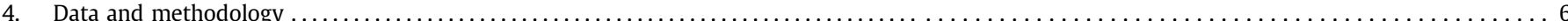

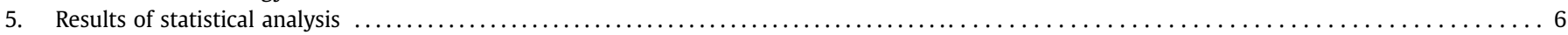

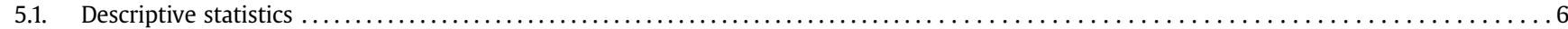

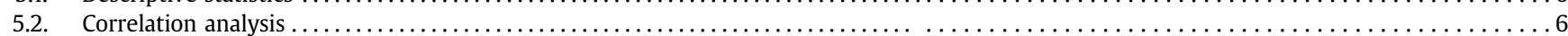

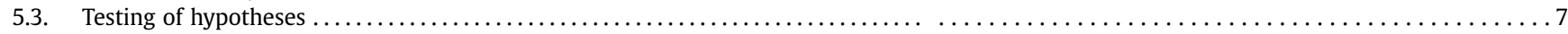

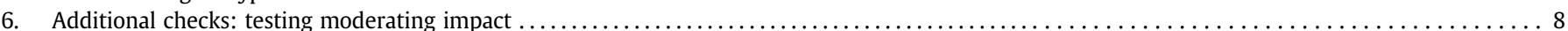

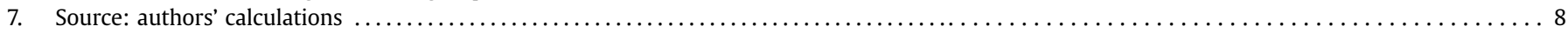

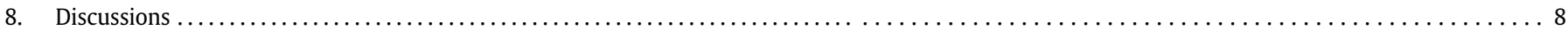

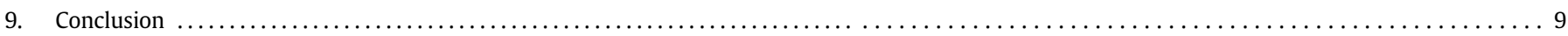

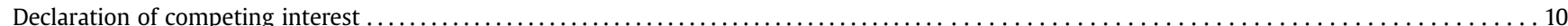

\footnotetext{
* Corresponding author.

E-mail addresses: Anthony.okafor@louisville.edu(A. Okafor),ngozi.adeleye@ covenantuniversity.edu.ng (B.N. Adeleye), madusei.ksb@knust.edu.gh (M. Adusei).
} 
Dear Editor,

\section{Introduction}

The increasing focus on corporate social responsibility and the calls to inculcate social responsibility principles in high-tech industries motivates us to explore the relationship between corporate social responsibility and firm performance in the high-tech industry in the U.S. Since the turn of the 21st century, the technology industries across the globe including those in the United States have witnessed significant growth. In the U.S, technology firms account for $32 \%$ of the market capitalization of listed firms on the S\&P 500 Index, and they represent the largest components of the Nasdaq Composite and Nasdaq-100 indices. There is no doubt that technology companies have witnessed significant growth over the last decade. On average, technology firms have seen over 375\% growth in revenue in the last decade, and the sector witnessed over $43 \%$ income growth in the last three years.

Technology companies have risen to prominence, dictating and directing economic trajectory, having a profound influence on national security and the societal well-being of citizens and the environment (Henry-Nickie et al., 2019). In the U.S, technology firms influence the allocation of resources and income distribution across the different strata of society. The developmental model of these high energy-dependent companies has undoubtedly come at a considerable cost to the environment and society (Lloret, 2016). Their commitment to engendering sustainable development has continued to dominate discussions. Therefore, environmental sustainability, social responsibility, and sustainable development among economic agents are taking center stage and becoming a strategic goal woven around organizational activities in the industry.

The radical changes in the ecosystem being perpetuated by the 4th industrial revolution in which technology is simultaneously creating wealth and causing environmental degradation is fueling the demand for social responsibility and accountability of companies in the tech industry. Severo et al. (2018) reinforce the important relationship between cleaner production in the context of social responsibility and eco-innovation, noting that sustainable consumption can be achieved over time with increased environmental awareness. Social expectations are varied, but the recurring themes include respect for human rights, environmental sustainability, eliminating all forms of discrimination in the workplace, and reducing the effect of organizational activities on the environment. Concerns about sustainable development, environmentalism, and corporate governance have also crept into these social expectations (Wang et al., 2020).

Authors are unanimous in their view of the importance and role of corporate social responsibility in achieving sustainable development (Abbas, 2020; Shirasu and Kawakita, 2020). The authors espoused that long-term growth can be achieved if firms focus not only on their shareholders but also on their broader stakeholders' interests through corporate governance and CSR activities. New areas of CSR opportunities are emerging in the industry, including cyber-security, artificial intelligence, green energy, robotization of workplace processes, the reorganization of jobs and social structures because of the use of big data. More budgetary allocations will have to be made to achieve these objectives, given the expectation that workplace digitization will be achieved by 2030 . Responsible corporate citizenship is another emerging trend in CSR viewed from an organization's commitment to respecting human rights and protecting the environment.

A previous study by Bernal-Conesa, de Nieves Nieto, and Briones-Peñalver (2017) identifies CSR's adoption as a strategy for improving the performance, competitiveness, and sustainability of tech companies operating in Spain. While investigating the impact of economic policy uncertainty on establishing a nexus between CSR and corporate financial performance, Rjiba et al. (2020) found that social capital investments through CSR activities limit the negative effect of economic policy uncertainty on financial performance. Presently in the U.S, a growing number of firms in the technology industry believe they have the duty to contribute to economic growth in a sustainable manner, evolve operational processes and practices that enhance their competitive advantage, and ensure the protection of the environment while promoting social responsibility. Therefore, since CSR initiatives could be a way to strengthen competitive advantage, organizations in the tech industry are interested in how spending on CSR activities influence firm performance over time.

Given the arguments above, in this study, we assess the effect of CSR practices on the financial performance of tech firms in the U.S. We hypothesize that when firms increase spending on CSR activities, their financial performance is enhanced as a result and that corporate governance represents one of the channels through which corporate social responsibility influences firm performance. Hence, this study investigates the CSR-financial performance nexus of the top 100 tech companies listed on the S\&P 500 Index based on their market capitalization. Essentially, we provide empirical evidence on CSR's impact on the financial performance of leading tech firms listed on the S\&P 500 Index.

Our most significant contribution to the literature is two folds. We provide evidence of a positive association between a firm's spending on CSR initiatives and revenue growth. Thus, our evidence suggests that technology companies with increased spending on CSR initiatives experience significant revenue growth. We note that most companies in the dataset witnessed a corresponding increase in revenue in line with CSR spending. Second, following our moderation analysis, we identify corporate governance as a channel through which CSR can be harnessed to enhance firm financial performance. In other words, our findings suggest that financial performance may be improved by instituting effective corporate governance that allows the organization to not only focus on its stockholders but its broader stakeholders.

Our study may provide additional insights to academics, practitioners, and regulators seeking to evolve frameworks or policies capable of stimulating technology companies' social responsibility and cohesion. From an academic standpoint, a vast majority of literature assessing the impact of CSR practices on firm financial performance, especially in the U.S, has scarcely focused on the technology industry. This is the first study to assess how spending on CSR initiatives influence firm performance in the technology industry to the best of our knowledge. Similarly, practitioners, including regulators, could leverage this study's unique findings to craft strategies to enhance their competitive advantage and achieve sustainable development.

The remaining part of this paper is structured as follows: Section 2 contains a comprehensive review of the literature. In section 3 , 
we discuss the theoretical underpinning and methodology adopted in the study. Section 4 includes a discussion of the results, and in section 5 , we provide the concluding remarks.

\section{Literature review}

The term social responsibility has different definitions and has continued to evolve, both in meaning and practice. Perhaps, the most granular of the existing definitions is the one provided by the International Organization for Standardization (ISO) where they described social responsibility as "the responsibility of an organization for the impacts of its decisions and activities on society and the environment, through transparent and ethical behavior that contributes to sustainable development" (ISO 26000:2010). A social responsibility initiative does not automatically translate into economic benefit for an organization; in fact, whatever benefits are derivable will be based on consumers' assessment of such initiatives as they relate to the activities of the business, not merely the act. The concept of CSR also requires organizations to create a safe working environment that addresses diversity and encourages the fair distribution of the organization's profit in society in an ethical manner (Zulfiqar, 2019). The challenge for most organizations has been how to achieve a balance that works for all the parties. The arguments in favor of CSR are that corporations can only continue to be socially responsible on the strength that the business strives with equally satisfied shareholders and investors.

Hou (2019) notes that organizations devote significant resources to CSR activities and deploy the same as an innovative stimulus for value creation, preservation, and a means of responding to changes in the culture of stakeholders. In another context, corporations embark on CSR activities as a corrective measure to address challenges created by the business or conditions existing prior to the commencement of the company. From an altruistic standpoint, organizations equally deploy CSR as a philanthropic activity to assist disadvantaged communities by providing amenities and other enabling infrastructures. For instance, leading tech giants in the U.S have intervened directly in their host communities or developed applications that are widely used and seen as a form of a contribution to society. Hamidu, Haron, and Amran (2015) identify the core issues enunciated by the proponents of CSR to include balancing competing stakeholders' claims with corporate resources and financial transparency and accountability to shareholders and other stakeholders. This is because CSR provides a framework that allows organizations to manage externalities. Elements of voluntarism give organizations the latitude to assume responsibilities and go beyond legal minimums in society's interest and multiple stakeholders.

Broadly, researchers have dimensioned how CSR activities affect corporate performance into three different categories. First, there is a growing argument that engaging in CSR has a positive effect on corporate financial performance, even though this argument is being disputed (Orlitzky et al., 2003). Engaging in CSR activities is identified as a means of boosting an organization's ethical identity. Berrone, Surroca, and Tribó (2007) argue that firms with a strong ethical identity go ahead to achieve substantial stakeholder satisfaction, which in turn impacts the financial performance of the firm positively. Giannarakis et al. (2016) analyzed a sample of 104 U.S companies across nine leading industries listed on the S\&P 500 Index between 2009 and 2013. They find that involvement in socially responsible initiatives has a significantly positive effect on financial performance. Control variables, such as total compensation to directors, CEO duality, and women's presence on board, were found to influence financial performance statistically. Oh, Hong and Hwang (2017) further corroborate this outcome when they investigated both strategic and traditional CSR's relationships with financial performance based on the confidence in the effectiveness of CSR. Fonseca and Ferro (2016) investigated the relationship between social performance and critical business results by studying a large sample comprising of small and medium-sized Portuguese firms. The study provides evidence that companies that implement socially responsible policies and satisfy the expectations of their stakeholders have higher economic benefits than competitors and achieve positive differentiation.

Using a 2015 survey response from 212 participants whose organizations are involved in corporate social responsibilty, Oh et al. (2017) find that traditional CSR initiatives significantly influence firm performance compared to strategic CSR initiatives. Further, the study provides empirical evidence about how financial performance is influenced by technology-focused R \& D, technology commercialization, and CSR. Following the same trajectory, Resmi et al. (2018) observe a sample of four agribusiness industries between 2015 and 2017 using a purposeful sampling technique. The study reviews the effect of CSR on agribusinesses in terms of profitability and assesses the relationship between CSR and EPS of firms in the agribusiness industry. The findings reveal that CSR has a significant effect on the net income and the return on firms' equity.

The second category of researchers has a contrary perspective that CSR activities hurt financial performance. Leading this group is a study by Zhu (2009). It determines the degree of corporate social responsibility on select stocks listed on the Shanghai stock exchange and corporate financial performance. The final results show that corporate performance decreases with the fulfillment of corporate social responsibility for most companies. Han, Kim, and Yu (2016) examine the relationship between corporate social responsibility and corporate profit by testing the ESG performance score on the financial performance of firms listed in the Korean stock market between 2008 and 2014. The study's findings reveal no statistically significant evidence or a relationship between CSR performance score and financial performance. Similarly, Moore (2009) reviews the effect of changes in companies' CSR fulfillments on financial performance. The result shows that revenue and CSR are negatively correlated and that environmental CSR scores have a negative impact on firm financial performance.

The third category of researchers finds no correlation between CSR and corporate financial performance. Nelling and Webb (2009) report no statistically significant relationship between CSR and corporate financial performance when the effects of time-series are excluded. They argue that with a robust research model, the previous positive correlation between CSR and financial performance will weaken as CSR engagements cannot increase the financial performance of firms. Surroca, Tribo, and Waddock (2010) note that the inability of previous studies to account for the mediating effect of intangible resources in the design process is another reason for the inconsistencies in the correlation results. Thus, research design errors account for the positive correlations between CSR and corporate financial performance, as reported by previous studies. Other than errors resulting from research design, the inconsistencies in the relationship between CSR and corporate performance can be attributed to sampling errors and biases, failure to explain cause and effect, and the absence of control variables in the model.

Rather than aligning perspectives with other researchers on the impacts of CSR on financial performance, efforts are now being made to recalibrate CSR initiatives to ensure they serve all stakeholders' interests. Keys, Malnight, and Graaf (2009) identify the mapping of CSR initiatives to understand the objectives of current initiatives, the benefits being created, and who benefits from such initiatives, as well as whether such initiatives fit into the long-term objective of the company as means of achieving a mutually 
beneficial CSR initiative. This would ensure that both parties benefit from any CSR initiative. Further, organizations could adopt smart partnering. The focus will be to develop critical areas of impact that meet social and business objectives to address the challenges that affect both parties.

The key to running an effective social initiative involves having a comprehensive strategy woven around the CSR activity. A properly designed CSR framework will integrate economic, social, and environmental decision-making so that the strategy is clearly understood within the organization and its partners in the supply chain. In terms of sustainable development, a well-articulated CSR framework could be used as an entry point for understanding and anticipating potential sustainable developmental issues and strategies to address them if and when they arise.

The attention of previous CSR studies has largely been focused on the banking sector, the traditional finance industries, the manufacturing industry, and a combination of most stocks listed on specific stock exchanges. This study is a departure from the usual trajectory because it focuses specifically on the tech companies and attempts to analyze the effect of CSR engagements on the corporate financial performance of the top 100 tech companies listed on the S\&P 500 Index. The choice of this sector is evident because technology firms account for $32 \%$ (see Fig. 1) of the market capitalization of the firms listed on the index and $87 \%$ of tech firms listed on the S\&P Index. In addition, this sector has witnessed over $43 \%$ income growth in the last three years.

Concerns about the tech industry's social contract, especially in California, considered as the home state for most tech companies, is particularly acute. While tech companies budget significant amounts yearly for CSR, residences of their host communities are at a loss as to what CSR looks like in reality. For instance, the presence of tech giants in California is blamed for gentrification and the spike in the cost of living in the region, which is now ranked highest in the country. Unlike the manufacturing industry with CSR strategies woven around their operations, the reality appears different for tech companies. Engaging in CSR activities seems straightforward in the manufacturing sector, obviously because of their visibility and the measurable impact of their businesses on the environment.

The most significant value-addition the technology sector contributes is in the area of capturing, analyzing, and sharing data. One that comes to mind is the Google map. Google's web mapping service is used extensively to offer satellite imagery to ease mobility and transportation. Governments and relief agencies use this device to identify areas affected by flood or devastated by other natural disasters. Another is Facebook's safe mark tool used during emergencies to ascertain the safety of the people in the area of

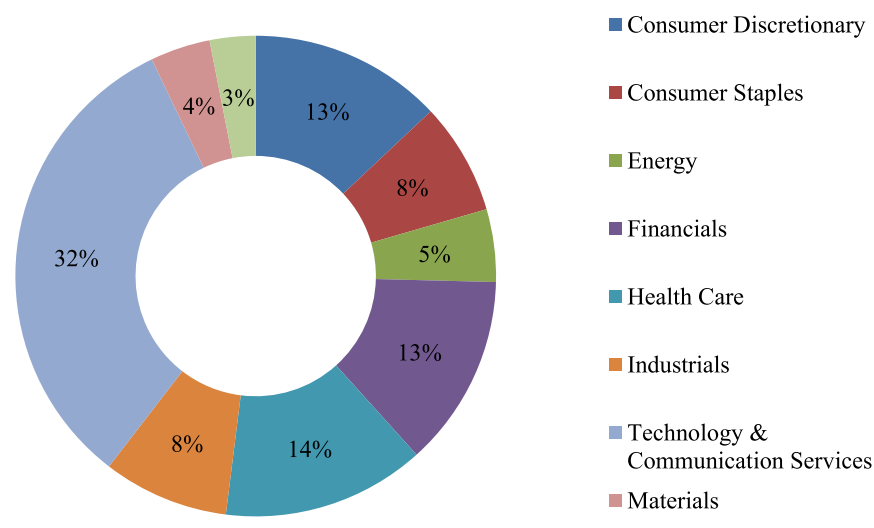

Fig. 1. Industry per market capitalization. Source: Authors'Computations from S\&P 500 index. interest. The challenge remains how these contributions affect the corporate performance of firms in the industry because these types of contributions are difficult to measure. Therefore, understanding whether a relationship exists or not about engaging in CSR activities is an essential issue for management in this industry. Consequently, if socially responsible activities add value to the corporations, more firms in the industry may be encouraged to engage in such activities going forward.

\section{Theoretical background and hypotheses}

The stakeholder theory presents the most consistent argument that an organization has a wider stakeholder, not just the shareholders and investors of the corporation. Shareholder primacy has led to a number of unfavorable outcomes for firms, economies, and society (Stout, 2012). The bulk of the thinking about the stakeholder theory of organizational management and business ethics emanated from Freeman (1984). He argued that a firm should create more value for all stakeholders, not just the firm's stockholders. The CSR concept plays a significant role in expanding Freeman's thinking and cementing the relationship between organizations and their stakeholders. We draw a nexus between Freeman's intervention and the critical function of CSR to highlight how tech organizations could focus on their ethical responsibilities to their multiple constituencies. Establishing this relationship is particularly important, given the difficulty in identifying industry stakeholders, unlike manufacturing companies that sell physical products. For instance, the online place is a complicated environment with heterogeneous interests that need to be satisfied. As high energy users, the activities of technology firms have implications on the environment, a silent stakeholder, whose interest is most often ignored. Therefore, the stakeholder theory underscores the need for organizations to identify these multiple stakeholders and tailor organizational processes to meet their needs.

Donaldson and Preston (1995) categorize stakeholder theory into three approaches: normative, descriptive, and instrumental. The normative approach describes the function of corporations and the identification of the philosophical guidelines necessary for the operation and management of corporations (Valentinov and Hajdu, 2019). The descriptive approach explains corporate behaviors, including the nature of the firm, the ways managers are managing, and how board members view the interests of corporate constituencies. The instrumental approach highlights the role of trust and cooperation in creating organizational wealth and competitive advantage. However, when stakeholders are dimensioned according to their legitimacy, power, and urgency, some stakeholders may exhibit both normative and instrumental tendencies.

The resource-based view of the firm is another framework that enables us to explain how organizations can leverage CSR as an internal strategy to achieve competitive advantage and sustainable development. Mowery, Oxley, and Silverman (1998) argue that an enterprise can best be described as a collection of difficult-toimitate resources and capabilities. These resources and capabilities are unique to the business, and that a business could explore these resources instead of focusing on the competitive environment. Similar to the resource-based view, the natural resourcebased view, as articulated by Hart (1995), helps to situate the scope of this study properly. The natural resource based-view extends the resource-based view and identifies pollution prevention, product stewardship, and sustainable development as a means of achieving competitive advantage. The integration of sustainable development in organizational processes helps in balancing stakeholder's economic, environmental, and social needs (Fonseca et al., 2020). Therefore, we argue that CSR activities are innate capabilities that organizations in this industry could leverage to gain a 
competitive advantage. For instance, the shift toward achieving low carbon emission, green energy, and pollution prevention, originally promoted by environmentalists, is now a thriving multi-billiondollar industry yielding immeasurable returns to players in the industry. Consequently, leveraging resource-based view theory, we posit that the adoption of CSR strategy is a lever for organizational change and sustainable development.

The study adopts a tripartite theoretical framework, as enunciated above. Essentially, we hinge our investigation on the instrumental approach to stakeholder theory and the theory of competitive advantage as espoused in the resource-based view framework to determine the effect of CSR initiatives on corporate financial performance. Despite the increasing importance of CSR, little attention is paid by previous studies to the effect of CSR on the financial performance of firms in the U.S tech industry. We expand this discourse by introducing corporate governance as another channel through which CSR improves corporate financial performance. Considering the tech industry's systemic importance to the U.S economy, this study attempts to focus on how businesses in this sector can contribute to addressing societal challenges or the needs of the immediate communities where they operate. The benefits of this, we reckon, are two folds. It enables organizations to become socially responsible to their stakeholders while simultaneously benefiting from engaging in CSR activities. CSR initiatives in the tech sector are deemed a philanthropic gesture to the communities in which businesses operate and not as a duty or means of eliciting external stakeholders' cooperation. This thinking is fueled by the narrow value creation theory, which focuses on a select set of stakeholders, mostly the corporation.

This study adopts the procedures set by Margolis and Walsh (2003) to examine the impact of CSR performance on the corporate financial performance of the top 100 tech companies listed on the S\&P 500 Index. This relationship is examined by determining whether spending on CSR activities reduces or improves firms' performance and whether corporate governance and an organization's climate change rank improves a company's reputation in a manner that exerts a positive effect on its financial performance. Our approach also mirrors Maqbool and Zameer (2018). They adopted net profit margin (NPM), return on assets (ROA), return on equity (ROE), firm value, revenue growth as proxies for corporate financial performance, and the ISS-ESG rating score as proxies for assessing CSR. The result shows that organizations take advantage of CSR to procure consumer trust and loyalty, which invariably yields beneficial business outcomes.

\subsection{Research hypotheses}

Empirical studies seeking to determine the correlation between CSR and firm financial performance have yielded varied results. Some have returned a positive correlation between the two variables (Cho et al., 2019; Oh et al., 2017), while researchers (Han et al., 2016; Zhu, 2009) report a negative correlation between the two constructs. The disparity in the outcome of these studies has led to a widespread search for a robust research design that leverages lagging indicators, while market-based indicators are leading indicators. We integrate both metrics to examine the relationship between CSR and corporate financial performance using our research sample. To determine how CSR influences firms' financial performance in this industry, the following hypotheses are established:

Hypothesis (H1). CSR has a statistically significant influence on revenue growth

To validate this hypothesis, the paper uses an accounting metric to assess the sales growth of the firm within the study period because an increase or decrease in revenue implies how effective a company is managing its assets. We contend that CSR activities improve the fortunes of corporations if done strategically and with the hope of extracting future economic benefits. Saeidi et al. (2015) observe that philanthropic activities could have a longtime positive effect on sales in the same manner that a good or bad reputation could attract or dispel customers from a business. The competitive advantage obtained thereof can lead to increased customer patronage and, ultimately, the revenue profile of the firm. Revenue growth is computed by comparing period 2 and period 1 sales figures as shown in Eqn 1

Revenue growth $=\frac{\text { Period } 2 \text { Net Sales }- \text { Period } 1 \text { Net Sales }}{\text { Period I Net Sales }}$

Hypothesis (H2). CSR has a statistically significant influence on profitability

To examine this hypothesis, the paper utilizes the net profit margin as a proxy to measure a firm's profitability, see Eqn 2. This depicts the ratio of the net income a company generates from its total sales or revenue. Organizational activities are directed in such a way that it enhances the bottom-line. Increased profitability and firm performance can be associated with CSR activities (Wang and Sarkis, 2017).

Net Profit Margin $=\frac{\text { Net Income }}{\text { Net Sales }}$

Hypothesis (H3). CSR has a statistically significant influence on firm value

Tobin's Q (TQ) value will be used as a proxy to determine the firm's value. Previous studies have used only accounting metrics, which are often subject to manipulation. Tobin's $Q$ value is forwardlooking and considers both accounting and market-based metrics, and not easily susceptible to management's manipulation. Fu, Singhal, and Parkash (2016) argue that Tobin's Q is positively correlated to a firm's value since it measures its investment and growth potentials. Tobin's $Q$ is calculated as shown in Eqn 3:

\footnotetext{
Market value of common stocks and shares outstanding + market value of preferred stocks + Book value

Tobin's $Q=\frac{\text { of long }- \text { term debt }}{\text { Replacement cost measured as the book value of assets }}$
}

both accounting and market-based metrics to determine firms' financial performance. Accounting-based metrics are typically
Hypothesis (H4). CSR has a statistically significant influence on ROA 
Hypothesis 4 examines the effect of CSR on ROA used in this study as a proxy for corporate financial performance. Previous studies such as Pan et al. (2014) find CSR to have a significant effect on ROA when they examine panel data of 228 listed Chinese mineral firms between 2010 and 2013. ROA is computed as shown in Eqn 4:

$R O A=\frac{\text { Operating Income }}{\text { Total Assets }}$

Hypothesis (H5). CSR has a statistically significant influence on ROE

Hypothesis 5 evaluates the statistical relationship between CSR and return on equity (ROE). We hypothesize that CSR initiatives impact an organization's stock value. The choice of ROE as a dependent variable aligns with (Shirasu and Kawakita, 2020). ROE is determined by comparing the net income and stockholder's equity as shown in Eqn 5.

$R O E=\frac{\text { Net Income }}{\text { Stockholder's Equity }}$

\section{Data and methodology}

The financial data, including the names of the top 100 tech companies listed on the S\&P 500 Index, were obtained to conduct this empirical analysis. The 10-K SEC filings of the selected companies between 2017 and 2019 financial year were analyzed to obtain data on financial performance and firm-specific characteristics. A total of 267 samples were obtained from 97 of the companies that met the strict requirement to be included in the sample. The minimum sample size of 97 was obtained using $G *$ Power 3.1 statistical software in line with Okafor (2018). The market valuation of the firms included in the analysis represents $87 \%$ of tech companies listed in the S\&P 500 Index. Since the sample represents 87\% of the technology firms listed on the S\&P 500 Index, we are therefore confident that the findings can be extended to other companies in the industry.

Once the companies are identified, a list of the sample is prepared to determine the computations for net profit margin, revenue growth, return on assets, return on equity, and firm value using Tobin's Q. We include key attributes from the Institutional Shareholder Services (ISS) ESG rating score to measure corporate social responsibility. The ISS-ESG rating score is developed and managed by the investment research arm of ISS, which conducts comparative research into companies' efforts and contributions to matters relating to the environment, social and governance issues, as well as companies aspiring to meet sustainable development goals (SDG). ISS-ESG rating score was considered the most appropriate CSR indicator because of its credibility in issuing sustainability reports.

The ISS-ESG rating score is analyzed using three distinct dimensions: employee relations, environment, and corporate governance (Guler et al., 2010). To improve this instrument, human rights ranking, climate change ranking, and spending on CSR activities determined via content analysis of the annual reports of the respective firms are included to strengthen the instrument. The dependent variables are net profit margin, revenue growth, return on assets, return on equity, and Tobin's $Q$, while the independent variables are employee relations, environment, corporate governance, human rights ranking, climate change ranking, and spending on CSR activities. We control the effect of firm age in the regression and fixed-effect model, which had a muted impact after several iterations. To engage the research hypotheses, the data were subjected to a battery of analysis. Descriptive and correlation analyses are used to observe the properties of the variables and the relative association between them, while econometric analysis using the fixed effects model is deployed to determine if any significant relationship exists between the two constructs.

Before proceeding with the tests, the data's normality is examined and found to be normally distributed. To avoid heteroscedasticity, the variables are tested to ensure no variability in the range of values used in the analysis. The fitting of the model is ascertained using Pearson and Hosmer-Lemeshow goodness-of-fit test, which produce a p-value of $0.026<0.05$, evidencing the model as a good fit for the study.

\section{Results of statistical analysis}

\subsection{Descriptive statistics}

Using 267 observations, the descriptive statistics of the dependent and independent variables are presented in Table 1 . The five dependent variables are net profit margin (NPM), return on assets $(R O A)$, return on equity $(R O E)$, revenue growth $(R G)$, and firm value $(T Q)$, while the independent variables are the variables used to assess CSR obtained from the ISS-ESG disclosure scores. They include spending on CSR activities (CSRS), environment (ENV), employee relations (EMP), climate change rank (CCR), human rights rank (HRR), and governance (CG). The firm age (AGE) is included as a control variable. The average Tobin's $Q$ in the firms in the sample is about $61 \%$. On average, the firms in the sample made about a $7 \%$ return on their assets. The average spending on CSR was $\$ 46$ million, while some companies spent as much as $\$ 2.2$ billion on CSR. The descriptive statistics also showed that the companies in the sample were ranked 85 and 257 on average in terms of employee relations and corporate governance, respectively. The average human rights ranking for firms in the model is put at 92 .

\subsection{Correlation analysis}

Table 2 shows the correlation matrix of the two-tailed test, including the correlation coefficients and the statistical significance of the variables. The Pearson correlation test is conducted using six CSR related variables: spending on CSR, environment, employee relations, corporate governance, human rights ranking, and climate change ranking. Corporate financial performance is measured by Tobin's $\mathrm{Q}$ as a proxy for firm value, ROA, ROE, profitability, and

Table 1

Summary of descriptive statistics.

\begin{tabular}{llllll}
\hline Variable & Obs & Mean & Std.Dev. & Min & Max \\
\hline TQ & 267 & 0.607 & .376 & 0 & 3.9 \\
ROA & 267 & 7.065 & 7.129 & -17.052 & 37.337 \\
CSRS & 267 & 45990.53 & 234000 & 64 & 2160000 \\
RG & 267 & -38.089 & 754.462 & -12300 & 338.984 \\
AGE & 267 & 78.835 & 49.28 & 1 & 228 \\
CG & 267 & 256.569 & 226.076 & 1 & 965 \\
ER & 267 & 84.631 & 65.938 & 1 & 323 \\
ENV & 267 & 77.91 & 68.73 & 1 & 486 \\
HRR & 267 & 92.24 & 94.855 & 1 & 583
\end{tabular}

ROE $26732.10251 .63-3141.31218 .27$

CCR 26780.9269 .1361323 .33

NPM $26711.5412 .278-72.1052 .57$

$\mathrm{TQ}=$ Tobin's $\mathrm{Q} ; \mathrm{ROA}=$ return on assets; $\mathrm{CSRS}=\mathrm{CSR}$ spending; $\mathrm{RG}=$ Revenue growth rate; $\mathrm{AGE}=$ Age of the firm; $\mathrm{CG}=$ Corporate governance rank; $\mathrm{ER}=$ Employee relations rank; $\mathrm{ENVR}=$ Environment; $\mathrm{HRR}=$ Human rights rank. $\mathrm{ROE}=$ Return on equity; $C C R=$ Climate change rank. 
Table 2

Correlation analysis.

\begin{tabular}{|c|c|c|c|c|c|c|c|c|c|c|c|c|}
\hline Variables & (1) & (2) & (3) & (4) & (5) & (6) & (7) & (8) & (9) & (10) & (11) & (12) \\
\hline (1) $\mathrm{TQ}$ & 1.000 & & & & & & & & & & & \\
\hline (2) ROA & 0.218 & 1.000 & & & & & & & & & & \\
\hline (3) CSRS & -0.119 & 0.152 & 1.000 & & & & & & & & & \\
\hline (4) RG & 0.009 & -0.028 & 0.011 & 1.000 & & & & & & & & \\
\hline (5) AGE & 0.007 & -0.086 & -0.059 & -0.062 & 1.000 & & & & & & & \\
\hline (6) CG & 0.062 & 0.069 & -0.051 & -0.071 & 0.239 & 1.000 & & & & & & \\
\hline (7) ER & 0.109 & 0.045 & -0.046 & 0.056 & -0.020 & 0.009 & 1.000 & & & & & \\
\hline (8) CCR & 0.088 & -0.051 & -1.330 & 0.004 & -0.142 & -0.012 & 0.058 & 1.000 & & & & \\
\hline (9) HRR & -0.026 & 0.055 & -0.032 & 0.016 & -0.074 & 0.150 & 0.089 & -0.167 & 1.000 & & & \\
\hline (10) ROE & -0.004 & 0.161 & 0.008 & -0.003 & 0.060 & 0.124 & 0.100 & -0.039 & 0.047 & 1.000 & & \\
\hline (11) ENVR & -0.046 & -0.090 & -0.058 & -0.258 & -0.095 & 0.174 & -0.008 & 0.188 & 0.074 & 0.026 & 1.000 & \\
\hline (12) NPM & 0.040 & 0.670 & 0.008 & -0.063 & -0.059 & 0.059 & -0.025 & 0.102 & 0.068 & 0.115 & -0.048 & 1.000 \\
\hline
\end{tabular}

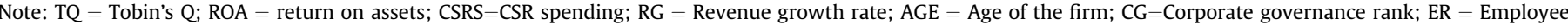
relations rank; $\mathrm{FR}=$ Financial rank; HRR= Human rights rank.

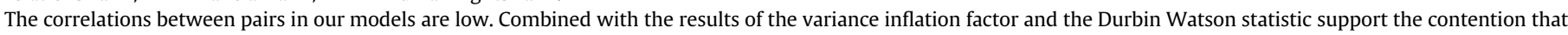
our models do not suffer from the multicollinearity problem.

revenue growth. Furthermore, Table 2 provides no evidence of multicollinearity, which may bias our findings.

\subsection{Testing of hypotheses}

The research hypotheses are tested using multiple regression, fixed-effects, and pooled regression techniques.

$\mathrm{H}_{1}$ : CSR has a statistically significant influence on revenue growth

$$
\begin{aligned}
& R G_{i t}=\alpha+\beta_{1} C S R S_{i t-1}+\beta_{2} E R_{i t-1}+\beta_{3} E N V_{i t-1}+\beta_{4} C G_{i t-1} \\
& \quad+\beta_{5} H R R_{i t-1}+\beta_{6} C C R_{i t-1}+\beta_{7} A G E_{i t-1}+\varepsilon_{i t}
\end{aligned}
$$

The effect of CSR on revenue growth produced a statistically significant result. Revenue growth was positively associated with the amount spent on CSR activities at a p-value of 0.005. This finding is particularly significant as this relationship has rarely been tested and represents part of our contribution. The result shows a model that is statistically significant at a p-value of 0.002 . The adjusted $R^{2}$ is $8.2 \%, \beta=123.11, F=3.146$, and $t=1.036$. The effect of the environment on revenue growth was found to be significant at a p-value of 0.001 (see Table 3). Employee relations, corporate governance, and human rights ranking were not correlated with revenue growth and did not affect the dependent variable. The

Table 3

Regression results.

\begin{tabular}{llllll}
\hline Variables & NPM & RG & ROE & ROA & TQ \\
\hline CSRS & 4.412 & $5.101^{* * *}$ & $0.010^{* * *}$ & $4.669 * *$ & $-1.687 *$ \\
& $(0.892)$ & $(0.005)$ & $(0.000)$ & $(0.013)$ & $(0.090)$ \\
CG & 0.004 & -0.252 & 0.121 & $0.002 * * *$ & 6.145 \\
& $(0.279)$ & $(0.219)$ & $(0.869)$ & $(0.007)$ & $(0.556)$ \\
ENV & -0.015 & $-2.800^{* * *}$ & -1.089 & -0.010 & 0.000 \\
& $(0.180)$ & $(0.001)$ & $(0.654)$ & $(0.146)$ & $(0.262)$ \\
CCR & $0.020 * *$ & 0.474 & 0.964 & -0.002 & 0.000 \\
& $(0.037)$ & $(0.483)$ & $(0.690)$ & $(0.711)$ & $(0.159)$ \\
ER & -0.007 & 0.530 & -2.313 & 0.005 & $0.001 *$ \\
& $(0.568)$ & $(0.440)$ & $(0.347)$ & $(0.128)$ & $(0.065)$ \\
HRR & 0.007 & $0.279 *$ & -0.341 & 0.004 & 0.000 \\
& $(0.410)$ & $(0.084)$ & $(0.845)$ & $(0.319)$ & $(0.413)$ \\
AGE & -0.017 & -1.015 & $0.185 *$ & -0.014 & -1.866 \\
& $(0.289)$ & $(0.288)$ & $(0.068)$ & $(0.119)$ & $(0.877)$ \\
Adjusted $\mathrm{R}^{2}$ & $2.4 \%$ & $8.2 \%$ & $44.3 \%$ & $4.8 \%$ & $3.7 \%$ \\
\hline
\end{tabular}

Note: $*, * *, * * *$ indicates statistical significance at the $90 \%, 95 \%$, and $99 \%$ levels, respectively.

Note: TQ = Tobin's Q; ROA $=$ return on assets; $C S R S=C S R$ spending; $R G=$ Revenue growth rate; $\mathrm{AGE}=$ Age of the firm; $\mathrm{CG}=$ Corporate governance rank; $\mathrm{ER}=$ Employee relations rank; $\mathrm{FR}=$ Financial rank; HRR $=$ Human rights rank. computed VIF for the independent variables returned an average of 1.068 , which indicates the model is a good fit devoid of multicollinearity. Also, the Durbin Watson statistic of $2.0295<2.5000$ implies no autocorrelation in the model.

$\mathrm{H}_{2}$ : CSR has a statistically significant influence on profitability

$$
\begin{aligned}
& N P M_{i t}=\alpha+\beta_{1} C_{S R S} i t-1+\beta_{2} E R_{i t-1}+\beta_{3} E N V_{i t-1}+\beta_{4} C G_{i t-1} \\
& \quad+\beta_{5} H_{R R} R_{i t-1}+\beta_{6} C C R_{i t-1}+\beta_{7} A G E_{i t-1}+\varepsilon_{i t}
\end{aligned}
$$

This hypothesis tests the relationship between profitability and CSR related variables: The model was statistically not significant at a p-value of 0.380 as shown in Table 3. The explanatory power of CSR related variables is $2.4 \%$ as measured by the adjusted $\mathrm{R}^{2}$. The model's regression coefficient is $\beta=10.050, \mathrm{~F}=1.071$, and $\mathrm{t}=5.293$. Among all the CSR related variables, only climate change ranking was statistically significant at a $\mathrm{p}$-value $=0.037<0.05 ; \beta=0.020$ and $t=1.791$. The average VIF for the model is 1.006 , while the Durbin Watson statistic is $1.346<2.500$, implying multicollinearity and autocorrelation concerns were mitigated.

$\mathrm{H}_{3}$ : CSR has a statistically significant influence on firm value

$$
\begin{aligned}
& T Q_{i t}=\alpha+\beta_{1} C_{S R S} S_{i t-1}+\beta_{2} E R_{i t-1}+\beta_{3} E N V_{i t-1}+\beta_{4} C G_{i t-1} \\
& +\beta_{5} H_{R R} R_{i t-1}+\beta_{6} C C R_{i t-1}+\beta_{7} A G E_{i t-1}+\varepsilon_{i t}
\end{aligned}
$$

In Hypothesis 3, we evaluate the relationship between firm value and the CSR variables. We find no evidence to support the null hypothesis; hence the null hypothesis is rejected as the result shows no significant relationship between firm value and CSR. Only CSRS is statistically significant to firm value at a p-value of $0.090<0.10$. Other explanatory variables have no significant effect on firm value. The coefficient for the regression model is $\beta=0.577$, $F=1.580, t=9.541$ and had a $p$-value of 0.141 at a $1 \%$ and $10 \%$ confidence level, respectively. Our findings contradict Cho et al. (2019), which found firm value to be influenced by CSR but align with those of Nelling and Webb (2009). Model diagnostics indicate no multicollinearity with the average VIF value as 1.038 and no autocorrelation given the Durbin Watson value of $1.480<2.500$.

$\mathrm{H}_{4}$ : CSR has a statistically significant influence on ROA

$$
\begin{aligned}
& R O A_{i t}=\alpha+\beta_{1} C_{S R S} S_{i t-1}+\beta_{2} E R_{i t-1}+\beta_{3} E N V_{i t-1}+\beta_{4} C G_{i t-1} \\
& \quad+\beta_{5} H R R_{i t-1}+\beta_{6} C C R_{i t-1}+\beta_{7} A G E_{i t-1}+\varepsilon_{i t}
\end{aligned}
$$

Similarly, model 4 examines the effect of CSR on ROA. The result of the regression produced a mixed outcome. The model yielded a statistically significant result at a p-value of $0.065<0.10$. The regression shows an adjusted $R^{2}$ value of $4.8 \%, \beta=5.961, t=5.222$, 
$F=1.864$. By disaggregating the data, we found that corporate governance was statistically significant to ROA at a p-value of 0.007 . This result aligns with Bagh et al. (2017) on the presence of a significant relationship between CSR and ROA. In addition, firm's spending on CSR had a striking relationship with ROA at a significance level of 0.013 . This represents our second contribution, and we extend this by assessing the moderating effect of corporate governance of CSRS. There is no presence of autocorrelation in the model given a Durbin Watson statistic of $1.880<2.500$. Similarly, the average VIF value for each independent variable is 1.068 , indicating no multicollinearity in the model as shown in Table 4.

$\mathrm{H}_{5}$ : CSR has a statistically significant influence on ROE

$$
\begin{aligned}
& R O E_{i t}=\alpha+\beta_{1} C_{S R S} S_{i t-1}+\beta_{2} E R_{i t-1}+\beta_{3} E N V_{i t-1}+\beta_{4} C G_{i t-1} \\
& \quad+\beta_{5} H_{R R} R_{i t-1}+\beta_{6} C C R_{i t-1}+\beta_{7} A G E_{i t-1}+\varepsilon_{i t}
\end{aligned}
$$

Regarding model 5, the model examines the relationship between CSR variables and ROE. From the analysis, corporate governance is statistically significant to the return on equity at the $1 \%$ significance level with a $p$-value of 0.000 . The adjusted $R^{2}$ for the model is $44.3 \%, \beta=74.481, F=36.268$, and $t=0.183$. Our findings here corroborate those of (Cherian et al., 2019). Interestingly, CSRS was also statistically significant at a p-value of 0.000 and regression coefficients of $\beta=0.01$ and $t=14.497$. Autocorrelation and multicollinearity checks conducted provide no evidence as the average VIF is 1.060 , and the Durbin Watson statistic is 1.68 (See Table 4). The model shows that targeted CSR spending positively affects a firm's ROE and, by extension, shareholder's wealth.

\section{Additional checks: testing moderating impact}

Next, we interrogate whether corporate governance moderates the impact of CSR spending on firm performance. The moderation test followed a procedure set in Pivato et al. (2008), where they found that intermediate variables could best explain the business case for CSR. A typical example is the one provided by Li et al. (2017), where they found that the government's stringent environmental regulations in China moderated the influence of corporate environmental responsibility on a firm's financial performance. Similarly, when Martinez-Conesa et al. (2017) examined the effect of CSR on firm performance on 552 Spanish firms, they posit that innovation performance moderated the effect of CSR on firm performance.

The main independent variable is the natural logarithm of CSR spending. Two measures of financial performance are used: Tobin's $\mathrm{Q}$ and return on assets (ROA). It was necessary to separate the two variables for further assessment because of the preponderance of literature reporting a possible association between firm performance and Tobin'Q and ROA. We probe this relation by reestimating the models using the pooled OLS (main), and fixed effects (robustness) approaches. The composite results are reported in Table 5. Columns [1], [2], [5], and [6] relate to the pooled analyses, while [3], [4], [7], and [8] are from the fixed effects technique. Under both ROA and TQ measures of financial performance, CSR spending is positive in seven out of eight models at the $1 \%, 5 \%$, and

Table 4

Model summary.

\begin{tabular}{lllllll}
\hline Variables & Coefficient & F-stat & T-stat & p-value & VIF & Durbin Watson \\
\hline Model 1 & 123.11 & 3.146 & 1.036 & 0.002 & 1.068 & 2.029 \\
Model 2 & 10.050 & 1.071 & 5.293 & 0.380 & 1.006 & 1.346 \\
Model 3 & 0.5770 & 1.661 & 9.541 & 0.131 & 1.038 & 1.480 \\
Model 4 & 5.961 & 1.864 & 5.961 & 0.065 & 1.068 & 1.109 \\
Model 5 & 74.481 & 36.268 & 0.183 & 0.000 & 1.060 & 1.664 \\
\hline
\end{tabular}

$10 \%$ significance levels, respectively. In particular, the fixed effects regression results reported in column [7] show that corporate governance significantly moderates the impact of CSR spending on firm performance. The results provide additional evidence supporting our initial finding that spending on corporate social responsibility activities positively impacts firms' financial performance.

\section{Source: authors' calculations}

The new coefficient of CSR spending reduces marginally to 0.215 (that is, 0.235-0.02), implying that in the presence of good corporate governance, the effect of CSR spending on the financial performance of firms measured by Tobin's $Q$ diminishes. The implication is that corporate governance represents one of the channels through which corporate social responsibility influences firm performance, marking it our third contribution. Consequently, the robustness check results affirm the results of the regression analysis and allow us to posit that there is a moderating effect of some contingency factors between CSR and corporate financial performance. The control variables are revenue growth, firm age, corporate governance, employee relations, financial rank, and human rights rank. The predictive power of the four models improved significantly and lay approximately between $8 \%$ and $17 \%$. Collectively, the independent and control variables explain between $8 \%$ and $17 \%$ variations in the financial performance of the firms in the study. Spending on CSR activities exerts a positive and statistically significant effect on the financial performance of the firms. This implies that an increase in CSR spending drives the financial performance of the firms positively. This is a significant contribution to the literature, which provides further evidence to support previous findings. The summary of the regression analyses of the five hypotheses tested in the study is shown in Table 6. The findings of models 1, 4, and 5 are fully accepted, while hypotheses 2 and 3 are partially accepted.

\section{Discussions}

These model show that increased spending on CSR activities increases firm corporate performance. Our results affirm the theoretical underpinnings of the study. Disaggregating the results, we establish that revenue growth is positively associated with the amount spent on CSR activities at a p-value of 0.005 . To the best of our knowledge, this finding is particularly significant because this relationship has rarely been tested in the U.S tech industry and represents part of our contribution. This finding is in sync with other studies (Bernal-Conesa et al., 2017; Boulouta and Pitelis, 2014) outside the U.S, where they found social performance to be positively correlated with the economic performance of technology firms. As such, this affirms the predictive accuracy of the model employed in this study. This finding implies that technology firms in the U.S could enhance their financial performance and competitive advantage by leveraging CSR as a corporate strategy.

Our model also shows that the more an organization spends on CSR activities, the more its value is enhanced. Equally, the study shows that spending on CSR initiatives influences an organization's return on assets and the stock value. We also provide evidence that suggests that a firm's commitment to protecting the climate improves its profitability. Similarly, environmental protection is found to be associated with revenue growth. The implication of these results is of enormous importance, given the world's focus on reducing climate change and its effect on the environment. It, therefore, implies that an organization could contribute to environmental protection while simultaneously growing its profitability. 
Table 5

Main and robustness analyses.

\begin{tabular}{|c|c|c|c|c|c|c|c|c|}
\hline \multirow[t]{3}{*}{ Variables } & \multicolumn{2}{|l|}{ Pooled OLS } & \multicolumn{2}{|c|}{ Fixed Effects } & \multicolumn{2}{|l|}{ Pooled OLS } & \multicolumn{2}{|c|}{ Fixed Effects } \\
\hline & \multirow{2}{*}{$\frac{\mathrm{TQ}}{[1]}$} & \multirow{2}{*}{$\frac{\mathrm{ROA}}{[2]}$} & \multirow{2}{*}{$\frac{\mathrm{TQ}}{\text { [3] }}$} & \multirow{2}{*}{$\frac{\mathrm{ROA}}{[4]}$} & \multirow{2}{*}{$\frac{\mathrm{TQ}}{[5]}$} & \multirow{2}{*}{$\frac{\mathrm{ROA}}{[6]}$} & \multirow{2}{*}{$\frac{\mathrm{TQ}}{\text { [7] }}$} & \multirow{2}{*}{$\frac{\mathrm{ROA}}{[8]}$} \\
\hline & & & & & & & & \\
\hline CSR spending & $\begin{array}{l}-0.034^{* * *} \\
(0.013)\end{array}$ & $\begin{array}{l}0.463 * \\
(0.237)\end{array}$ & $\begin{array}{l}0.101 * \\
(0.06)\end{array}$ & $\begin{array}{l}1.532 * * * \\
(0.497)\end{array}$ & $\begin{array}{l}0.005 \\
(0.05)\end{array}$ & $\begin{array}{l}1.732 * \\
(0.922)\end{array}$ & $\begin{array}{l}0.235 * * * \\
(0.087)\end{array}$ & $\begin{array}{l}1.720 * * \\
(0.741)\end{array}$ \\
\hline Corporate governance & $\begin{array}{l}0.003 \\
(0.019)\end{array}$ & $\begin{array}{l}0.158 \\
(0.357)\end{array}$ & $\begin{array}{l}-0.01 \\
(0.018)\end{array}$ & $\begin{array}{l}0.114 \\
(0.288)\end{array}$ & $\begin{array}{l}0.064 \\
(0.077)\end{array}$ & $\begin{array}{l}2.14 \\
(1.438)\end{array}$ & $\begin{array}{l}0.151^{*} \\
(0.08)\end{array}$ & $\begin{array}{l}0.34 \\
(0.959)\end{array}$ \\
\hline CSR*Corporate & & & & & $\begin{array}{l}-0.008 \\
(0.01)\end{array}$ & $\begin{array}{c}-0.267 \\
(0.188)\end{array}$ & $\begin{array}{l}-0.020^{* *} \\
(0.01)\end{array}$ & $\begin{array}{r}-0.028 \\
(0.095)\end{array}$ \\
\hline Revenue growth & $\begin{array}{l}0.000 \\
(0.000)\end{array}$ & $\begin{array}{l}0.000 \\
(0.001)\end{array}$ & $\begin{array}{l}-0.000 * \\
(0.000)\end{array}$ & $\begin{array}{l}-0.001^{* * *} \\
(0.000)\end{array}$ & $\begin{array}{l}0.000 \\
(0.000)\end{array}$ & $\begin{array}{l}0.000 \\
(0.001)\end{array}$ & $\begin{array}{l}-0.000 * * \\
(0.000)\end{array}$ & $\begin{array}{l}-0.001^{* * *} \\
(0.000)\end{array}$ \\
\hline Firm age & $\begin{array}{l}0.022 \\
(0.03)\end{array}$ & $\begin{array}{l}-0.095 \\
(0.56)\end{array}$ & $\begin{array}{l}-0.333 \\
(0.436)\end{array}$ & $\begin{array}{l}-4.604 \\
(4.656)\end{array}$ & $\begin{array}{l}0.021 \\
(0.03)\end{array}$ & $\begin{array}{c}-0.12 \\
(0.559)\end{array}$ & $\begin{array}{l}-0.352 \\
(0.423)\end{array}$ & $\begin{array}{l}-4.631 \\
(4.66)\end{array}$ \\
\hline Employee relations & $\begin{array}{l}0.040 * \\
(0.02)\end{array}$ & $\begin{array}{l}0.296 \\
(0.38)\end{array}$ & $\begin{array}{l}0.088 * * \\
(0.043)\end{array}$ & $\begin{array}{l}0.650 * \\
(0.354)\end{array}$ & $\begin{array}{l}0.039 * \\
(0.02)\end{array}$ & $\begin{array}{l}0.281 \\
(0.38)\end{array}$ & $\begin{array}{l}0.086 * * \\
(0.043)\end{array}$ & $\begin{array}{l}0.647 * \\
(0.356)\end{array}$ \\
\hline Financial rank & $\begin{array}{l}-0.049 * * \\
(0.02)\end{array}$ & $\begin{array}{l}-1.564^{* * *} \\
(0.376)\end{array}$ & $\begin{array}{l}-0.074^{* *} \\
(0.036)\end{array}$ & $\begin{array}{l}-0.366 \\
(0.306)\end{array}$ & $\begin{array}{l}-0.048^{* *} \\
(0.02)\end{array}$ & $\begin{array}{l}-1.533^{* * *} \\
(0.376)\end{array}$ & $\begin{array}{l}-0.069 * \\
(0.035)\end{array}$ & $\begin{array}{l}-0.359 \\
(0.311)\end{array}$ \\
\hline Human rights & $\begin{array}{l}-0.019 \\
(0.018)\end{array}$ & $\begin{array}{l}0.291 \\
(0.335)\end{array}$ & $\begin{array}{l}-0.079 * \\
(0.046)\end{array}$ & $\begin{array}{l}-0.056 \\
(0.346)\end{array}$ & $\begin{array}{l}-0.019 \\
(0.018)\end{array}$ & $\begin{array}{l}0.299 \\
(0.334)\end{array}$ & $\begin{array}{l}-0.074 \\
(0.046)\end{array}$ & $\begin{array}{l}-0.048 \\
(0.355)\end{array}$ \\
\hline Constant & $\begin{array}{l}0.919 * * * \\
(0.226)\end{array}$ & $\begin{array}{l}8.656 * * \\
(4.209)\end{array}$ & $\begin{array}{l}1.6 \\
(1.75)\end{array}$ & $\begin{array}{l}12.868 \\
(18.926)\end{array}$ & $\begin{array}{l}0.624 \\
(0.424)\end{array}$ & $\begin{array}{c}-0.862 \\
(7.898)\end{array}$ & $\begin{array}{l}0.587 \\
(1.756)\end{array}$ & $\begin{array}{l}11.444 \\
(19.825)\end{array}$ \\
\hline Observations & 265 & 265 & 265 & 265 & 265 & 265 & 265 & 265 \\
\hline Time dummies & Yes & Yes & Yes & Yes & Yes & Yes & Yes & Yes \\
\hline No. of Firms & $\mathrm{N} / \mathrm{A}$ & $\mathrm{N} / \mathrm{A}$ & 97 & 97 & $\mathrm{~N} / \mathrm{A}$ & $\mathrm{N} / \mathrm{A}$ & 97 & 97 \\
\hline R-squared & 0.074 & 0.097 & 0.156 & 0.076 & 0.077 & 0.104 & 0.169 & 0.076 \\
\hline F-statistic & $2.28 * *$ & $3.03 * * *$ & $13.20 * * *$ & $700.16 * * *$ & $2.11 * *$ & $2.94 * * *$ & $16.77 * * *$ & $643.16 * * *$ \\
\hline
\end{tabular}

Note: ***, **and * denotes statistical significance at $1 \%, 5 \%$ and $10 \%$ levels, respectively; robust standard error in ( ); TQ = Tobin's Q; ROA = Return on Assets.

Table 6

Summary of findings.

\begin{tabular}{lll}
\hline Hypothesis & Test Performed & Outcomes \\
\hline $\mathrm{H}_{1}$ & CSR has a statistically significant influence on revenue growth & Accepted \\
$\mathrm{H}_{2}$ & CSR has a statistically significant influence on profitability & Partially accepted \\
$\mathrm{H}_{3}$ & CSR has a statistically significant influence on firm value & Partially accepted \\
$\mathrm{H}_{4}$ & CSR has a statistically significant influence on return on assets & Accepted \\
$\mathrm{H}_{5}$ & CSR has a statistically significant influence on return on equity & \\
Sources: Authors' Compilation & & \\
\hline
\end{tabular}

Further, using the fixed effect and pooled OLS, we identify corporate governance as a channel through which CSR can be used to improve corporate financial performance. In other words, we provide evidence that suggests that corporate financial performance may be improved by instituting effective corporate governance that allows the organization to focus not only on its stockholders but also on its larger stakeholders. Our findings contradict the conclusions reached by Borghesi et al. (2019), where they posit that better run companies do not outperform poorly run companies. However, our result is in accord with the position canvassed by Paniagua et al. (2018), where they found corporate governance and financial performance to be positively associated, thereby reinforcing the accuracy of our model.

\section{Conclusion}

The effect of CSR on firm performance has been widely studied in the literature with varying conclusions. This study extends prior empirical studies by examining CSR's effect on the financial performance of tech firms. The overarching intention of this study is to determine the effect of CSR related variables, namely spending on CSR activities, corporate governance, employee relations and environment, climate change rank, and human rights rank on financial performance indicators: firm profitability, firm value, return on assets, return on equity, and revenue growth. The paper focuses on technology firms and analyzes a sample of 97 tech companies listed on the S\&P 500 Index between 2017 and 2019.

The findings are mixed. Notably, the results reveal a significant relationship between spending on CSR activities and growth in revenue. Companies in the tech industry see the fulfillment of corporate social responsibility as fundamental to improving growth and guarantying long-term financial performance. We also establish that corporate governance represents one of the channels through which corporate social responsibility influences firm performance. During the study period, companies such as Apple, Amazon, Cisco Systems, Microsoft, and others witnessed a corresponding increase in revenue in line with CSR spending. Similarly, spending on CSR is found to be positively correlated with profitability. The average net profit margin of companies analyzed grew from $10.7 \%$ to $18.5 \%$ within the period, further reinforcing the study's findings.

In hypotheses 4 and 5 , corporate governance is statistically significant to return on assets and return on equity. Investors are becoming increasingly attracted to well-managed companies, which reflects how the firms' assets are deployed to generate wealth for stockholders. Investors are becoming committed to sustainable development causes, which represents material ESG (environmental, social, and governance) perspectives that investors consider when deciding investment targets and as part of their fiduciary responsibility. Firms that align their organizational 
strategies with these goals have a substantial investment case and are expected to secure appreciable returns because of the competitive advantage that comes with it.

This paper contributes to the literature and complements the existing studies seeking to establish a relationship between CSR and financial performance. A critical finding of this empirical research is that CSR spending positively affects a firm's revenue growth and profitability. This finding is vital to both academics and practitioners. It allows them to craft strategic CSR initiatives that impact their stakeholders, knowing that such efforts would contribute to financial performance over time. This study also highlights the importance and contribution of governance structures on return on assets and return on equity. The empirical research expands the frontiers of knowledge and provokes further discussions about the subject.

Overall, there is limited literature on the relationship between CSR and financial performance in the tech industry; hence, the study's outcome contributes to the extant literature. While this study's outcome may be generalized to companies in the technology industry, the results may not be generalized to other sectors of the economy. More importantly, future studies could focus on identifying additional channels through which CSR impacts the financial performance of firms. Also, since this study has applied three years of data, further investigation may require an extended timeframe for additional insights. Subject to data availability, other variables not included in the analysis, such as location and demographics, may be considered in subsequent research.

The authors confirm that this research did not receive any grant from funding agencies either in the public, commercial, or not-forprofit sectors, as such none of the authors have any conflict of interest in respect of this paper.

\section{Declaration of competing interest}

The authors declare that they have no known competing financial interests or personal relationships that could have appeared to influence the work reported in this paper.

\section{References}

Abbas, J., 2020. Impact of total quality management on corporate green performance through the mediating role of corporate social responsibility. J. Clean. Prod. 242 (1), 1-12.

Bagh, T., Khan, M.A., Azad, T., Saddique, S., Khan, M.A., 2017. The corporate social responsibility and firms' financial performance: evidence from financial sector of Pakistan. Int. J. Econ. Financ. Issues 7 (2), 301-308.

Bernal-Conesa, J.A., de Nieves Nieto, C., Briones-Peñalver, A.J., 2017. CSR strategy in technology companies: its influence on performance, competitiveness, and sustainability. Corp. Soc. Responsib. Environ. Manag. 24 (2), 96-107.

Berrone, P., Surroca, J., Tribó, J.A., 2007. Corporate ethical identity as a determinant of firm performance: a test of the mediating role of stakeholder satisfaction. J. Bus. Ethics 76 (1), 35-53. https://doi.org/10.1007/s10551-006-9276-1.

Boulouta, I., Pitelis, C.N., 2014. Who needs CSR? The impact of corporate social responsibility on national competitiveness. J. Bus. Ethics 119, 349-364. https:// doi.org/10.1007/s10551-013-1633-2.

Borghesi, R., Chang, K., Li, Y., 2019. Firm value in commonly uncertain times: the divergent effects of corporate governance and CSR. Appl. Econ. 51 (43), 4726-4741.

Cherian, J., Umar, M., Thu, P.A., Nguyen-Trang, T., Sial, M.S., Khuong, N.V., 2019. Does corporate social responsibility affect the financial performance of the manufacturing sector? Evidence from an emerging economy. Sustainability 11 (4), $1-14$.

Cho, S.J., Chung, C.Y., Young, J., 2019. Study on the relationship between CSR and financial performance. Sustainability 11 (2), 343.

Donaldson, T., Preston, L.E., 1995. The stakeholder theory of the corporation: concepts, evidence, and implications. Acad. Manag. Rev. 20 (1), 65-91.

Fonseca, L., Ferro, R., 2016. Does it pay to be social responsible? Portuguese SMEs feedback. Intang. Cap. 12 (2), 487-505. https://doi.org/10.3926/ic.712.

Fonseca, L.M., Domingues, J.P., Dima, A.M., 2020. Mapping the sustainable development goals relationships. Sustainability 12 (8), 3359.

Freeman, R.E., 1984. Strategic Management: A Stakeholder Approach. Cambridge university press.
Fu, L., Singhal, R., Parkash, M., 2016. Tobin's q ratio and firm performance. International research journal of applied finance 7 (4), 1-10.

Giannarakis, G., Konteos, G., Zafeiriou, E., Partalidou, X., 2016. The impact of corporate social responsibility on financial performance. Invest. Manag. Financ. Innovat. 13 (3), 171-182.

Guler, A., Aybars, A., Kutlu, O., 2010. Managing corporate performance: investigating the relationship between corporate social responsibility and financial performance in emerging markets. Int. J. Prod. Perform. Manag. 59, 229-256. https:// doi.org/10.1108/17410401011023573.

Hamidu, A.A., Haron, H.M., Amran, A., 2015. Corporate social responsibility: a review on definitions, core characteristics and theoretical perspectives. Mediterr. J. Soc. Sci. 6 (4), 83-95. https://doi.org/10.5901/mjss.2015.v6n4p83.

Han, J., Kim, H.J., Yu, J., 2016. Empirical study on relationship between corporate social responsibility and financial performance in Korea. Asian Journal of Sustainability and Social Responsibility 1, 61-76. https://doi.org/10.1186/s41180016-0002-3.

Hart, S.L., 1995. A natural-resource-based view of the firm. Acad. Manag. Rev. 20 (4), 986-1014.

Henry-Nickie, M., Frimpong, K., Sun, H., 2019. Trends in the information technology sector. The Brookings Institute Retrieved from. https://www.brookings.edu/.

Hou, T.C.T., 2019. The relationship between corporate social responsibility and sustainable financial performance: firm-level evidence from Taiwan. Corp. Soc. Responsib. Environ. Manag. 26 (1), 19-28.

ISO 26000, 2010. International Standard, Guidance on Social Responsibility. International Organization for Standardization, Geneva.

Keys, T., Malnight, T.W., Van Der Graaf, K., 2009. Making the most of corporate social responsibility. McKinsey Q. 36, 38-44.

Lloret, A., 2016. Modeling corporate sustainability strategy. J. Bus. Res. 69 (2), $418-425$.

Li, D., Cao, C., Zhang, L., Chen, X., Ren, S., Zhao, Y., 2017. Effects of corporate environmental responsibility on financial performance: the moderating role of government regulation and organizational slack. J. Clean. Prod. 166, 1323-1334.

Maqbool, S., Zameer, M.N., 2018. Corporate social responsibility and financial performance: an empirical analysis of Indian banks. Future Business Journal 4 (1), 84-93.

Margolis, J.D., Walsh, J.P., 2003. Misery loves companies: rethinking social initiatives by business. Adm. Sci. Q. 48 (2), 268-305.

Martinez-Conesa, I., Soto-Acosta, P., Palacios-Manzano, M., 2017. Corporate social responsibility and its effect on innovation and firm performance: an empirical research in SMEs. J. Clean. Prod. 142, 2374-2383.

Moore, M., 2009. CSR \& company financial performance. https://doi.org/10.2139/ ssrn.3377842. Available on Social Science Research Network.

Mowery, D.C., Oxley, J.E., Silverman, B.S., 1998. Technological overlap and interfirm cooperation: implications for the resource-based view of the firm. Res. Pol. 27 (5), 507-523.

Nelling, E., Webb, E., 2009. Corporate social responsibility and financial performance: the "virtuous circle" revisited. Rev. Quant. Finance Account. 32 (2), 197-209.

Oh, S., Hong, A., Hwang, J., 2017. An analysis of CSR on firm financial performance in stakeholder perspectives. Sustainability 9 (6), 1023-1035.

Okafor, A., 2018. Impact of valuation methods on the likelihood of mergers and acquisitions of high-tech startups companies in Nigeria. Available from ProQuest Digital Dissertations and Theses database, pp. 1-194. https://doi.org/ 10.13140/RG.2.2.12789.12006.

Orlitzky, M., Schmidt, F.L., Rynes, S.L., 2003. Corporate social and financial performance: a meta-analysis. Organ. Stud. 24 (3), 403-441.

Pan, X., Sha, J., Zhang, H., Ke, W., 2014. Relationship between corporate social responsibility and financial performance in the mineral Industry: evidence from Chinese mineral firms. Sustainability 6 (7), 4077-4101.

Paniagua, J., Rivelles, R., Sapena, J., 2018. Corporate governance and financial performance: the role of ownership and board structure. J. Bus. Res. 89, 229-234.

Pivato, S., Misani, N., Tencati, A., 2008. The impact of corporate social responsibility on consumer trust: the case of organic food. Bus. Ethics Eur. Rev. (17), 3-12.

Resmi, S.I., Begum, N.N., Hassan, M.M., 2018. Impact of CSR on firm's financial performance: a study on some selected agribusiness industries of Bangladesh. American Journal of Economics, Finance and Management 4 (3), 74-85.

Rjiba, H., Jahmane, A., Abid, I., 2020. Corporate social responsibility and firm value: guiding through economic policy uncertainty. Finance Res. Lett. 35, 1-7.

Saeidi, S.P., Sofian, S., Saeidi, P., Saeidi, S.P., Saaeidi, S.A., 2015. How does corporate social responsibility contribute to firm financial performance? The mediating role of competitive advantage, reputation, and customer satisfaction. J. Bus. Res. 68 (2), 341-350.

Severo, E.A., de Guimarães, J.C.F., Dorion, E.C.H., 2018. Cleaner production, social responsibility and eco-innovation: generations' perception for a sustainable future. J. Clean. Prod. 186, 91-103.

Shirasu, Y., Kawakita, H., 2020. Long-term financial performance of corporate social responsibility. Global Finance J. 1-66. https://doi.org/10.1016/j.gfj.2020.100532.

Stout, L.A., 2012. The Shareholder Value Myth: How Putting Shareholders First Harms Investors, Corporations, and the Public. Berrett-Koehler Publishers.

Surroca, J., Tribó, J.A., Waddock, S., 2010. Corporate responsibility and financial performance: the role of intangible resources. Strat. Manag. J. 31 (5), 463-490.

Valentinov, V., Hajdu, A., 2019. Integrating instrumental and normative stakeholder theories: a systems theory approach. J. Organ. Change Manag. Advance online publication https://doi.org/10.1108/JOCM-07-2019-0219.

Wang, Y., Lu, T., Qiao, Y., 2020. The effect of air pollution on corporate social 
responsibility performance in high energy-consumption industry: evidence from Chinese listed companies. J. Clean. Prod. 280 (2021), 1-12.

Wang, Z., Sarkis, J., 2017. Corporate social responsibility governance, outcomes, and financial performance. J. Clean. Prod. 162, 1607-1616.

Zhu, Y., 2009. Empirical test on the relationship between corporate social responsibility and financial performance. Stat. Decis. 7, 135-137.

Zulfiqar, S., Sadaf, R., Popp, J. Vveinhardt, J., Máté, D., 2019. An examination of corporate social responsibility and employee behavior: the case of Pakistan. Sustainability 11 (13), 3515. 